\title{
NUTRIENT COMPOSITION OF CATERPILLARS, PUPAE, COCOONS AND ADULTS OF THE EASTERN TENT MOTH, MALACOSOMA AMERICANUM (LEPIDOPTERA: LASIOCAMPIDAE)
}

\author{
Eugene H. Studier, John O. Keeler and Steven H. Sevick \\ Department of Biology, University of Michigan-Flint, Flint, MI 48502-2186, U.S.A. \\ Telephone: 313-762-3360
}

(Received 26 February 1991)

\begin{abstract}
Levels of the elements- $-\mathrm{N}, \mathrm{Na}, \mathrm{K}, \mathrm{Mg}, \mathrm{Ca}$, and $\mathrm{Fe}-$ in caterpillars, pupae, cocoons and adults of Eastern tent moths show individual patterns for each element.

2. As food, all stages exceed minimal mammalian and avian requirements for $\mathbf{N}, \mathbf{M g}$, and $\mathrm{K}$; however, for $\mathrm{Na}, \mathrm{Fe}$, and $\mathrm{Ca}$, at least one stage is nutritionally inadequate for mammals and birds.
\end{abstract}

\section{INTRODUCTION}

Eastern tent moths in all stages of development are eaten by various predators, e.g., birds (Knapp and Casey, 1986) and bats (Black, 1972). Body composition analyses of prey items are required to establish nutrient budgets of such insectivorous animals. Caloric content of many insects has been studied (Cummins and Wuycheck, 1971; Schroeder, 1977; Slansky and Scriber, 1984); however, scant other compositional data have been reported. This study reports body composition for the elements- $\mathrm{N}, \mathrm{Na}$, $\mathrm{K}, \mathrm{Mg}, \mathrm{Ca}$ and $\mathrm{Fe}$-during growth of Eastern tent moth caterpillars, as well as in pupae, cocoons, and adults and compares whole body content of these nutrients to nutritional requirements of birds and mammals.

\section{MATERIALS AND METHODS}

Eastern tent moth caterpillars were collected in a county park in Genesee Co., MI, at about 10 day intervals from 2 May-13 June 1990 from several small black cherry trees (Prunus serotina), which represent a favorite food (Wadley, 1938). Some caterpillars collected on 1 and 13 June 1990 were returned to the laboratory and housed for a few days in a 10 gallon aquarium with fresh black cherry foliage as forage. Some caterpillars pupated within 2 days and pupae and cocoons were used as samples. Adult tent moths were collected at light traps during the night. All samples werc placed in plastic vials, kept cold on ice and frozen upon return to the laboratory.

Our primary interest in these insects is as food for predators; thus, individuals in all developmental stages were analysed whole, including gut contents, which may contribute significantly to reported composition. Samples were wet weighed (to the nearest $0.1 \mathrm{mg}$ ) and dried to constant weight at $50-60^{\circ} \mathrm{C}$. Dry samples of $40-145 \mathrm{mg}$ were digested and, after appropriate dilution, levels of $\mathrm{Na}, \mathrm{K}, \mathrm{Mg}, \mathrm{Ca}, \mathrm{Fe}$ (as ppt dry weight) and $\mathrm{N}$ (as \% dry weight) were determined (Treybig and Haney, 1983; Studier et al., 1988). Utilizing this methodology, the lowest detectable level of iron is about $0.01 \mathrm{ppt}$ and of sodium is about $0.001 \mathrm{ppt}$ dry weight. Up to 16 of the smallest caterpillars were required to obtain an adequate dry sample.
Data were stored in Lotus files and data analyses and graphics were done with SYSTAT and SYGRAPH (Wilkinson, 1988, 1989). For purposes of regression analyses, 2 May 1990 was designated day 0.

\section{RESULTS AND DISCUSSION}

The cohort of caterpillars we studied initiated pupation on about 1 June 1990; therefore, growth rates were estimated for the 30 day period of $2 \mathrm{May}-1$ June 1990. During that period of observation, caterpillar per cent body water rose gradually from $79 \%$ on day 0 to $85 \%$ on day 19 with a marked drop to $74 \%$ on day 30 . Associated with those changes in per cent body water, live weight rose from day 0 to day 19 but then remained constant until pupation began on about day 30 . Dry weight, however, rose linearly $\left(F=230.32, \mathrm{df}=1\right.$ and $\left.62, P<0.001, r^{2}=0.77\right)$ over the 30 day period as expressed by:

Dry weight $(\mathrm{g})=0.0034$ Time (in days) +0.0029 ,

where values in parentheses are standard errors. Dry mass growth rate, therefore, was $3.4 \mathrm{mg} / \mathrm{day}$, which seems typical for this species (Segarra-Carmona and Barbosa, 1983; Casey et al., 1988). Accretion of dry mass in the last 10 days prior to pupation was offset by a corresponding per cent body water decrease which accounts for the lack of live mass growth during that time span. Since caterpillars were weighed whole, reported growth rates include variable amounts of gut contents and, therefore, overestimate gut-empty caterpillar growth.

Wet and dry weights of pupae $(N=8)$ averaged $0.4329 \mathrm{~g}( \pm 0.0496)$ and $0.1060 \mathrm{~g}( \pm 0.0102)$, respectively to yield a water content of $74 \%$. Adult moth wet and dry weights $(N=7)$ averaged $0.1868 \mathrm{~g}$ $( \pm 0.0431)$ and $0.0652 \mathrm{~g}( \pm 0.0122)$, respectively for a water level of $65 \%$. High variability in pupal weight reflects similar variability in caterpillar size at pupation and in adult moth live weights, and appears to 
Table 1. Regression equation coefficients for various elements (in ppt) and caterpiliar dry weights (in $\mathrm{mg}$ ) for the Eastern tent moth, Malacosoma americanum

\begin{tabular}{lcccccc}
\hline Element & Intercept & Slope & $F$ & $P$ & $r^{2}$ & Accretion \\
\hline $\mathrm{Ca}$ & 1.022 & 0.0263 & 90.961 & $<0.001$ & 0.65 & 13.11 \\
& $(0.016)$ & $(0.0027)$ & & & & \\
$\mathrm{Fe}$ & 0.0519 & 0.0022 & 13.136 & $=0.001$ & 0.21 & 0.983 \\
& $(0.0370)$ & $(0.0006)$ & & & & \\
$\mathrm{Mg}$ & 2.942 & 0.0013 & 1.060 & $\mathrm{NS}$ & 0.02 & 10.48 \\
& $(0.076)$ & $(0.0013)$ & & & & \\
$\mathrm{Na}$ & 0.0233 & 0.0012 & 7.362 & $=0.009$ & 0.13 & 0.519 \\
& $(0.0260)$ & $(0.0004)$ & & & & \\
$\mathrm{K}$ & 25.984 & -0.049 & 12.407 & $=0.001$ & 0.21 & 70.39 \\
$\mathrm{~N}$ & $(0.815)$ & $(0.014)$ & 21.131 & $<0.001$ & 0.31 & 419.7 \\
& 162.24 & -0.360 & 2.131 & & & \\
\hline
\end{tabular}

Degrees of freedom $=1$ and 48 in all cases. Accretion is the rate of absolute accumulation of each element during caterpillar growth in $\mu \mathrm{g} /$ day.

be typical for this species (Segarra-Carmona and Barbosa, 1983).

Relationships of elemental concentrations (in ppt dry weight) to dry weight during caterpillar growth are given in Table 1. Although great variability (as evidenced by low $r^{2}$ values) exists, concentrations of $\mathrm{Ca}, \mathrm{Fe}$ and $\mathrm{Na}$ rise, $\mathrm{Mg}$ remains constant, and $\mathrm{K}$ and $\mathrm{N}$ fall during growth. These differences in caterpillar composition may reflect changes in the composition of plant tissue being consumed (Segarra-Carmona and Barbosa, 1983) as well as differences in gut fullness. Since significant amounts of $\mathrm{N}$ are contained in the exoskeleton, decrease in $\mathrm{N}$ concentration is likely to be related to decreases in surface area to mass ratio which accompany growth in caterpillars. The excessive $\mathrm{K}$ and very low $\mathrm{Na}$ levels in caterpillars certainly reflect the levels of those elements typically found in plants (Weeks, 1978). Table 1 also shows the absolute accretion (in $\mu \mathrm{g} /$ day) for each element measured. Values given in Table 1 are valid for tent moth caterpillars as food, but overestimate retention rates for gut-empty caterpillars.

Table 2 illustrates dry mass concentrations of measured elcments in pupac, cocoons and adults of Eastern tent moths. Values listed for each element for mammals and birds represent minimal requirements for growth and reproduction in those groups (National Research Council, 1978, 1984). Levels and patterns of concentrations differ for each element.

Dry $\mathrm{Fe}$ concentration rises slowly as caterpillars grow, becomes markedly higher in both pupae and cocoons and falls to $0(P<0.01 \mathrm{ppt})$ in adults. As vertebrate prey, therefore, caterpillars, cocoons and pupae provide adequate iron intake, but adult moths are an inadequate dietary iron source.

The pattern for calcium concentration is striking (Table 2) and is illustrated in Fig. 1. Calcium level rises markedly as caterpillars grow. At pupation, calcium is voided into the cocoons so that pupal levels are considerably reduced in comparison to large caterpillars while calcium levels in cocoons are extremely high. After metamorphosis, calcium concentration in adults is lowered further. Minimal calcium requirements for growing birds and mammals are quite high (Table 2) and unpublished studies in our laboratory indicate that few insect species provide adequate dietary $\mathrm{Ca}$. Very large caterpillars nearly meet minimal calcium requirements. Pupae $(t=4.43, \quad \mathrm{df}=7, \quad P<0.01)$ and adults $(t=12.6, \mathrm{df}=6, P<0.001)$ fall below the minimal mammalian requirement of $4.0 \mathrm{ppt}$. Cocoons contain extremely high $\mathrm{Ca}$ levels and would represent an excellent source of dietary calcium. Cocoons, therefore, might be actively ingested by growing or reproductively active birds and mammals. We know of no studies which test specific consumption of cocoons or "tents", and we have initiated such studies.

In growing caterpillars, dry magnesium levels remain constant at about $3.0 \mathrm{ppt}$. Levels are lower in pupae, adults, and cocoons; however, individuals at all life stages contain levels of this element which exceed nutritional needs of birds and mammals.

Sodium levels rise slightly during caterpillar growth but remain very low and no measurable sodium $(<0.001 \mathrm{ppt})$ was found in pupae or

Table 2. Dry weights ( $=$ dry thass in $\mathrm{mg}$ ) and levels of $\mathrm{Fe}, \mathrm{Ca}, \mathrm{Mg}, \mathrm{Na}$, and $\mathrm{K}$ in ppt dry weight as well as $\mathrm{N}$ in $\%$ dry weight in pupae, cocoons and adult Eastern tent moths, Malacosomo americanum

\begin{tabular}{lcccccccc}
\hline Sample & $N$ & D.W. & $\mathrm{Fe}$ & $\mathrm{Ca}$ & $\mathrm{Mg}$ & $\mathrm{Na}$ & $\mathrm{K}$ & $\mathrm{N}$ \\
Pupae & 8 & 102.8 & 0.59 & $1.87^{*}$ & 2.58 & $0^{*}$ & 8.08 & 11.12 \\
& & $(9.0)$ & $(0.12)$ & $(0.48)$ & $(0.10)$ & $(0)$ & $(0.24)$ & $(0.29)$ \\
Cocoon & 14 & 10.8 & 0.49 & 17.72 & 0.13 & $0.08^{*}$ & 2.83 & 22.55 \\
& & $(0.7)$ & $(0.12)$ & $(1.62)$ & $(0.05)$ & $(0.03)$ & $(0.75)$ & $(0.55)$ \\
Adult & 7 & 65.2 & $0^{*}$ & $0.85^{*}$ & 1.37 & $0^{*}$ & 8.26 & 16.50 \\
& & $(12.2)$ & $(0)$ & $(0.25)$ & $(0.08)$ & $(0)$ & $(0.57)$ & $(1.22)$ \\
Mammals & & & 0.02 & 4.0 & 0.4 & 0.5 & 2.0 & 1.9 \\
Birds & & & 0.08 & 6.5 & 0.3 & 1.5 & 4.0 & 3.5 \\
\hline
\end{tabular}

Values listed for mammals and birds are minimal requirements for growth for each element (National Research Council, 1978 and 1984, respectively). Lower resolution for $\mathrm{Na}$ level is about $0.001 \mathrm{ppt}$ and for $\mathrm{Fe}$ is about $0.01 \mathrm{ppt}$; therefore, values recorded as 0 are less than those levels. Concentrations marked with an asterisk fall below minimal avian and mammalian requirements for that element 


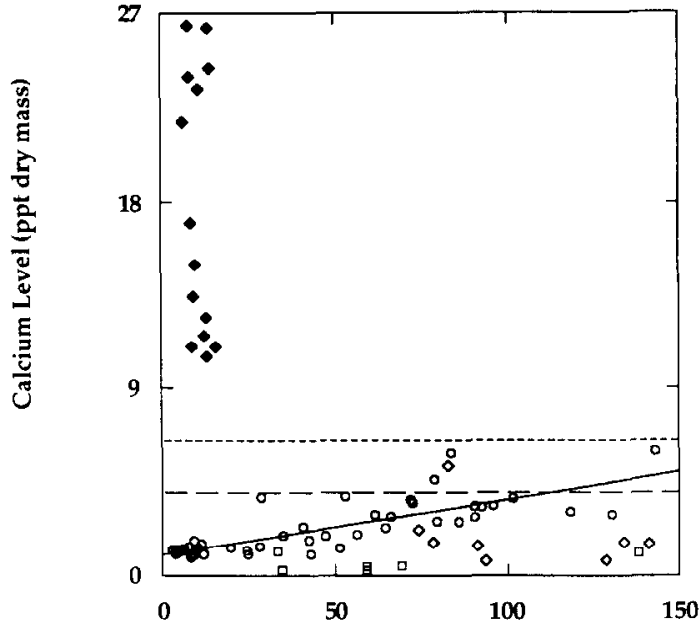

Dry Weight (mg)

Fig. 1. Calcium level (ppt dry mass) and dry weight (mg) of caterpillars (circles), pupae (open diamonds), cocoons (solid diamonds) and adults (squares) of the Eastern tent moth (Malacosoma americanum). The solid line represents the regression equation of calcium level versus dry weight in caterpillars (see Table 1). The long-dashed and short-dashed lines represent minimal nutritional requirement for calcium for small mammals and birds, respectively (National Research Council, 1978 and 1984, respectively).

adults. Sodium levels in cocoons are also below minimal mammalian requirement $(t=14.0, \mathrm{df}=13$, $P<0.001)$. Very large caterpillars may contain sufficient sodium to meet nutrient requirements of birds and mammals; however, Eastern tent moths at all other stages of growth and development represent inadequate dietary sodium sources.

Eastern tent moths in all stages of their life cycle provide more than adequate potassium sources. Potassium levels in caterpillars, which decrease with growth, are, in fact, very high. Such excessive potassium intake has been shown to increase dietary sodium need (Meyer et al., 1950; Staaland et al., 1980); therefore, ingestion of Eastern tent moth caterpillars as prey may worsen the marginal or negative sodium balance which would accompany a diet of these caterpillars.

Nitrogen content of Malacosoma americanum at any stage of development greatly exceeds nutritional requirements for that element. Since a significant amount of nitrogen would be bound as structural, aminated polysaccharides at all life cycle stages, available nitrogen would be less than the values given in Table 2. Adjustment of levels to account for unavailable nitrogen, however, would not be expected to lower those levels below minimal dietary $\mathrm{N}$ requirement.

In summary, as food for birds and mammals, $M$. americanum in all life stages provide sufficient amounts of $\mathrm{N}, \mathrm{Mg}$, and $\mathrm{K}$ to meet requirements for growth. All life stages are inadequate sources of $\mathrm{Na}$. All stages except adults provide adequate Fe. Very large caterpillars may and cocoons certainly do provide adequate dietary $\mathrm{Ca}$ but small caterpillars, pupae and adults do not.

Acknowledgements -We thank Margaret Rummel, Vickie Yott, Lynne Latra and Fern Gregor for their aid in both the field and laboratory. Dr R. Schenck provided useful comments on the manuscript. This study was supported in part by a Faculty Development Fund Grant from The University of Michigan-Flint.

\section{REFERENCES}

Black H. (1972) Differential exploitation of moths by the bats Eptesicus fuscus and Lasiurus cinereus. J. Mammal. 53, 598-601.

Casey T. M., Joos B., Fitzgerald T. D., Yurlina M. E. and Young P. A. (1988) Synchronized group foraging, thermoregulation and growth of eastern tent caterpillars in relation to microclimate. Physiol. Zool. 61, 372-377.

Cummins K. W. and Wuycheck J. C. (1971) Caloric equivalents for investigation in ecological energetics. Mitt. Internat. Verein. Limnol. 18, 1-158.

Knapp R. and Casey T. M. (1986) Thermal ecology, behavior, and growth of gypsy moth and eastern tent caterpillars. Ecology 67, 598-608.

Meyer J. H., Grunert R. R., Zepplin M. T., Grummer R. H., Bohstedt G. and Phillips P. H. (1950) Effect of dietary levels of sodium and potassium on growth and on concen. trations in plasma and tissues of the white rat. Am. J. Physiol. 162, 182-188.

National Research Council (1978) Nutrient Requirements of Laboratory Animals. No. 10, 3rd rev. edn, National Academy of Sciences, Washington, DC.

National Research Council (1984) Nutrient Requirements of Poultry. 8th rev. edn, National Academy of Sciences, Washington, DC.

Schroeder L. (1977) Distribution of caloric densities among larvae feeding on black cherry tree leaves. Oecologia 29, 219-222.

Segarra-Carmona A. and Barbosa P. (1983) Nutrition content of four rosaceous hosts and their effects on development and fecundity of the eastern tent caterpillar, Malacosoma americanum (Fab.) (Lepidoptera: Lasiocampidae). Can. J. Zool. 61, 2868-2872.

Slansky F., Jr and Scriber J. M. (1984) Food consumption and utilization. In Comprehensive Insect Physiology, Biochemistry and Pharmacology (Edited by Kerkut G. A. and Gilbert L. I.), Vol. 4, Chap. 3, pp. 87-162. Pergamon Press, Oxford.

Staaland H., White R. G., Luick J. R. and Holleman D. F. (1980) Dietary influences on sodium and potassium metabolism of reindeer. Can. J. Zool. 58, 1728-1734.

Studier E. H., Szuch E. J., Tompkins T. M. and Cope V. W. (1988) Nutritional budgets in free flying birds: cedar waxwings (Bombycilla cedrorum) feeding on Washington hawthorn fruit (Crataegus phaenopyrum). Comp. Biochem. Physiol. 89A, 471-474.

Treybig D. S. and Haney P. L. (1983) Calorimetric determination of total nitrogen in amines with selenium catalyst. Anal. Chem. 55, 983-985.

Wadley F. M. (1938) The eastern tent caterpillar. Leaflet No. 161, pp. 5, U.S. Dept. Agric., Washington, DC.

Weeks H. P. Jr (1978) Variation in the sodium and potassium content of food plants of wild Indiana herbivores. RB 957, Agric. Exper. Station, Purdue Univ., West Lafayette.

Wilkinson L. (1988) SYGRAPH. $\mathrm{xx}+\mathrm{pp} .980$. SYSTAT, Inc., Evanston, IL.

Wilkinson L. (1989) SYSTAT. The System for Statistics. $x+$ pp. 822. SYSTAT, Inc., Evanston, IL. 